Ritrýnd grein birt 31. desember 2020

\title{
Tíminn sem ég man eftir: Ávinningur nemenda af pátttöku í Skrekk, hæfileikakeppni grunnskóla Reykjavíkurborgar
}

\author{
Jóna Guðrún Jónsdóttir og Rannveig Björk Porkelsdóttir \\ Abstract \\ - Um höfunda \\ About the authors \\ Heimildir
}

Markmið rannsóknarinnar sem pessi grein byggir á var að stuðla að aukinni pekkingu á listkennslu og skoða hvaða áhrif pátttaka í verkefni eins og Skrekk, hæfileikakeppni grunnskóla Reykjavíkurborgar, hefur á líðan og sjálfsmynd ungmenna. Jafnframt var markmiðið að skoða áhrif Skrekks á skólabrag og skólamenningu. Rannsóknin byggir á eigindlegri rannsóknaraðferð. Tekin voru sextán viðtöl, átta við rýnihópa nemenda á unglingastigi og átta viðtöl við kennara og skólastjórnendur, úr fimm skólum. Einnig var fylgst með nemendum á úrslitakvöldi Skrekks í Borgarleikhúsinu. Niðurstöður rannsóknar leiddu í ljós að pátttaka í Skrekk hafði jákvæð áhrif á líðan og sjálfsmynd ungmenna, sér í lagi pegar pau fengu tækifæri til að vinna út frá eigin reynslu í námi og lýðræðislegum gildum. Einnig leiddi rannsóknin í ljós að pátttaka í Skrekk hefði góð áhrif á skólasamfélagið par sem mikil liðsheild skapaðist í kringum keppnina. Nemendur kynntust pvert á árganga og í ljós kom að peir litu á pátttöku sína sem afar dýrmætan tíma par sem peir söfnuðu jákvæðum minningum. Peir sögðu pað hafa aukið stolt peirra að taka pátt, jafnt pátttakenda sem áhorfenda pátttökuskóla, og peirra nemenda sem fylgdust með úr fjarlægð. Pannig urðu pátttakendur og áhorfendur hluti af Skrekkssamfélaginu par sem félagsleg tengsl mynduðust auk menningar- og samfélagslegra pátta sem höfðu áhrif á skólasamfélagið í heild. Á pann hátt urðu listirnar páttur í reynslunámi nemenda.

Efnisorð: Listgreinar, leiklist, reynslunám, lýðræði, skólasamfélag

\section{Inngangur}

Miklar breytingar hafa orðið í menntamálum á Íslandi si̊ðustu áratugi. Menntastefnan sem birtist í Aðalnámskrá grunnskóla frá 2013 leggur áherslu á sex grunnpætti menntunar, en peir eru læsi, sjálfbærni, heilbrigði og velferð, lýðræði og mannréttindi, jafnrétti og sköpun. Par segir m.a.: „Grunnskólinn á að proska með nemendum hæfni í anda grunnpáttanna og búa pá undir pátttöku í lýðræðissamfélagi“" (Mennta- og menningarmálaráðuneyti, 2013, bls. 36). Segja má að viss bylting hafi átt sér stað í íslensku grunnskólakerfi í kjölfar nýju aðalnámskrárinnar par sem reynt var að aðlaga hana breyttu samfélagi og heimsmynd sem leggur meðal annars aukna áherslu á velferð og lýðræði. Pegar grunnpættir menntunar eru skoðaðir nánar má sjá að hlutverk grunnskólanna er mjög yfirgripsmikið, ekki aðeins varðandi pað sem snýr að náminu sjálfu heldur einnig, og ekki síður, ýmsum páttum er lúta að alhliða proska einstaklingsins, andlegum og líkamlegum (Mennta- og menningarmálaráðuneyti, 2013). Til að takast á við áskoranir nútíma menntunar parf skólakerfið fjölbreytt tæki og tól til að koma til móts við nemendur. Menntunar- og námskrárfræðingurinn Elliot W. Eisner (2002) bendir á mikilvægi innsæis og ímyndunarafls í listum. Hann telur að peir pættir, samhliða pví að nemendur tileinki sér nýjar aðferðir og leiðir til að leysa viðfangsefni á skapandi hátt, 
geti komið skólakerfinu til góða (Eisner, 2002). Á hverju skólaári býður Reykjavíkurborg nemendum í grunnskólum borgarinnar að taka pátt í Skrekk, hæfileikakeppni grunnskóla Reykjavíkurborgar. Keppnin er undirbúin í samstarfi félagsmiðstöðva og grunnskólanna sem taka pátt og er hún haldin árlega í Borgarleikhúsinu. Í Skrekk próa og skapa nemendur atriði, að hámarki sjö mínútur, frá hugmynd til leiksýningar, sem eflir sköpunargáfu peirra. Einnig pjálfa peir samvinnu og styrkja sjálfsmynd sína og samkennd, auk pess að víkka sjóndeildarhring sinn. Pá styrkir pátttakan enn fremur skólasamfélagið í heild sinni, samhliða pví að auka samstarf skóla og félagsmiðstöðva (Skólaog frístundasvið Reykjavíkurborgar, 2014). Markmið rannsóknarinnar sem pessi grein byggir á er að stuðla að aukinni pekkingu á listkennslu og skoða hvaða áhrif pátttaka í verkefni eins og Skrekk hefur á líðan og sjálfsmynd ungmenna. Jafnframt er skoðað hvaða áhrif Skrekkur hefur á skólabrag og skólamenningu pátttökuskóla.

Viðfangsefni og rannsóknarspurningar eru eftirfarandi:

Hvernig telja ungmenni að pátttakaíSkrekk, hæfileikakeppnigrunnskóla Reykjavíkurborgar, tengist líðan peirra og sjálfsmynd?

Hver er birtingarmynd pátttöku í Skrekk á skólasamfélag pátttökuskóla?

Greinin er pannig uppbyggð að fyrst er gerð grein fyrir fræðilegum bakgrunni. Næst er framkvæmd rannsóknar lýst og síðan er fjallað um helstu niðurstöður rannsóknarinnar. Loks eru niðurstöður dregnar saman og túlkaðar.

\section{Bakgrunnur verkefnisins}

Hér verður fræðilegur bakgrunnur verkefnisins kynntur. Fjallað verður um Skrekk, hæfileikakeppni grunnskóla Reykjavíkurborgar, og hvað felst í hugtökunum reynslunám og lýðræði. Einnig verður fjallað um mikilvægi listgreinanna leiklist, tónlist og dans í almennu skólastarfi.

\section{Reynslunám og lýðræði í Skrekk, hæfileikakeppni grunnskóla Reykjavíkurborgar}

Markmið Skrekks, hæfileikakeppni grunnskóla Reykjavíkurborgar, er að nemendur á unglingastigi vinni að pví að skapa atriði, að hámarki sjö mínútna langt, frá hugmynd til sýningar. Keppnin er undirbúin í samstarfi félagsmiðstöðva og grunnskóla Reykjavíkurborgar. Sá háttur er hafður á að verkefnið er yfirleitt í vali á unglingastigi, ýmist í 9.-10. bekk eða 8.-10. bekk, allt eftir áherslum skólanna, svo allir sem vilja geta tekið pátt. Nemendur vinna að verkefninu frá byrjun skólaárs fram í nóvember eða fram að keppni sem haldin hefur verið í Borgarleikhúsinu síðustu ár. Peir grunnskólar er taka pátt sjá um að ráða leiðbeinanda eða kennara, einn eða fleiri, til að hafa yfirumsjón með Skrekkshópnum en einungis 35 nemendur mega keppa frá hverjum skóla, pó að fleiri nemendur komi oft að verkefninu innan hvers skóla meðan á æfingaferlinu stendur. Í skýrslu Skóla- og frístundasviðs (2014) kemur fram að með pátttöku sinni fái nemendur nám í formi reynslu par sem peir spegla sig í pví samfélagi sem peir búa í á skemmtilegan og áhrifaríkan hátt. Allir tilheyra peim hópi sem starfar að pví sameiginlega verkefni að skapa atriði fyrir keppnina. Í skýrslunni segir einnig að markmið keppninnar sé að nemendur efli sköpunargáfu sína og pjálfi samvinnu ásamt að styrkja sjálfsmynd sína og samkennd og efla skólasamfélagið í heild. Í Skrekk fá nemendur einnig tækifæri til að kljást við fjölbreytt og skapandi verkefni með virkni, frumkvæði og sköpun að leiðarljósi. Auk pess gefur verkefnið unglingum í grunnskólum Reykjavíkurborgar kost á að taka pátt í frístundastarfi par sem meðal annars er lögð áhersla á virka pátttöku, lýðræði og reynslunám (Skóla- og frístundasvið Reykjavíkurborgar, 2014).

Segja má að heimspekingurinn og menntunarfræðingurinn John Dewey hafi verið upphafsmaður reynslunáms en hann lagði mikla áherslu á að nemendur lærðu í gegnum reynsluheim sinn, í gegnum verklegt ferli par sem nemendur fyndu samhengi milli athafna og afleiðinga og lærðu pannig af reynslunni (Dewey, 2000; Jóhanna Einarsdóttir, 2010; Ólafur Páll Jónsson, 2010, 2011). Dewey 
taldi menntun vera félagslegt ferli sem byggði á jákvæðri og lýðræðislegri reynslu og ætti að vera tengt námsefninu. Hann sagði mikilvægt að auk hefðbundinna námsgreina tileinkuðu nemendur sér sjálfstæði í hugsun og viðhorfum. Nám átti að vera nemendamiðað og nemendur hvattir til pátttöku í eigin námi par sem reynsla peirra væri metin að verðleikum. Dewey sagði að reynslan ætti að vera tengd námsefninu sem myndi auka jákvæða upplifun nemenda af námi og verða peim hvetjandi reynsla sem styrktist í endurtekningu til framtíðar. Hlutverk kennarans væri að búa til skapandi og lýðræðislegar aðstæður par sem hver og einn einstaklingur fengi að eflast og proskast út frá eigin reynslu til framtíðar. Hugtakið lýðræði var einnig samofið hugmyndum Deweys um menntun par sem skólinn var hluti af stærra samhengi samfélagsins. Hann taldi lýðræði liggja í einstaklingnum sjálfum, í samvinnu einstaklinga, félagslegum tengslum hans og samspili við samfélagið sem hann tilheyrir par sem ólíkir hópar samfélagsins mynduðu tengsl, ynnu saman og lærðu hver af öðrum (Dewey, 2000). Hann taldi lýðræði vera opið samfélag par sem fólk af mismunandi uppruna ætti samskipti og ynni saman til að skilja og efla menntunarsamfélag sitt. Menntun væri mikilvægur páttur í lýðræðislegu samfélagi, par sem ólíkir nemendur ynnu saman til að öðlast meiri víðsýni og hæfni og auka pannig möguleika sína á að byggja nám á nýrri reynslu (Dewey, 1916; Jóhanna Einarsdóttir, 2010; Ólafur Páll Jónsson, 2010). Ólafur Páll Jónsson og Póra Björg Sigurðardóttir (2012) benda einnig á að lýðræði í skólasamfélagi feli meðal annars í sér gildi eins og virkni, hlustun, skapandi hugsun, gagnkvæma virðingu, gagnrýna samræðu, pátttöku og jafnrétti (Ólafur Páll Jónsson og Póra Björg Sigurðardóttir, 2012).

\section{Mikilvægi listgreina}

Prófessor Mike Fleming (2012) segir listir auka skilning fólks á heiminum; pær geti breytt ríkjandi hugmyndafræði og víkki sjóndeildarhring pess. Hann leggur áherslu á mikilvægi pess að kennsla í listum sé ekki aðeins til pess að nemendur geti tjáð sig með listsköpun heldur verði peir að fá tækifæri til að skoða og meta listir frá mörgum sjónarhornum. Pannig verði til aukin pekking í gegnum reynslu og skilning. Pví hefur verið haldið fram að listir séu umbreytandi á marga vegu par sem efniviðurinn er í stöðugri próun. Hugmyndir umbreytast í veruleika og samvinnan umbreytir manneskjunum sem taka pátt par sem veruleikinn er dreginn í efa og endurhugsaður. Pannig á sér stað félagsleg umbreyting í gegnum listir (Anderson, 2012; Neelands, 2015). Eisner (2002) telur eðli lista m.a. vera að skoða efni frá mismunandi sjónarhornum, að kynna sér fleiri en eina lausn á hverju viðfangsefni par sem ekkert eitt svar er endilega réttara en annað. Auk pess telur Eisner að listsköpun geti kennt fólki að innri vellíðan og ánægja skipti máli í pekkingarleit og sé hvati pess að pað taki sér eitthvað fyrir hendur. Með aðstoð lista er hægt að kenna nemendum að leita innri ánægju í gegnum verkefni sín í stað pess að vinna á vélrænan hátt par sem einkunnir verða miðpunkturinn (Eisner, 2002). Í rannsókn Rannveigar Bjarkar Porkelsdóttur (2016), dósents í leiklistarkennslu við Háskóla Íslands, kemur fram að listir hafi einnig áhrif á samfélag skóla og skólabrag. Skólastjórnendur sem tóku pátt í rannsókninni litu á pátttöku nemenda í leiklist sem ávinning fyrir allt skólasamfélagið par sem ólíkir nemendur purftu að vinna saman auk pess sem peir töldu listirnar efla skapandi hugsun nemenda (Rannveig Björk Porkelsdóttir, 2016). Jonothan Neelands (2015), prófessor við Háskólanum í Warwick, Bretlandi, er sama sinnis og segir að listir geti haft breiða skírskotun til lífs fólks og samfélags í formi umbreytinga.

Michael Anderson (2012), prófessor við háskólann í Sydney í Ástralíu, heldur pví fram að leiklist sé einstakt tæki til að nota í kennslu par sem hún sameinar bæði líkamlega og andlega pekkingu og sköpun. Kennarar hafi par öflugt tæki til að umbreyta nemendum og nútímavæða skólakerfið í takt við síbreytilegt samfélag. Rannveig Björk Porkelsdóttir (2016) tekur í svipaðan streng og telur að nemendur í leiklist proski tilfinningar sínar í gegnum samkennd og sjálfsstjórn. Peir efli sjálfstraust sitt og sköpunarkraft og proski tjáningu sína auk pess sem peir nái að styrkja félagslega hæfni sína og samvinnu. Hún segir sérstöðu leiklistar meðal annars felast í að hún vinni jöfnum höndum með vitsmuni, sköpun og líkamlegt atgervi. Pannig sé hún umbreytandi og geti styrkt samfélagslegan og tilfinningalegan pátt nemenda (Rannveig Björk Porkelsdóttir, 2016). Fleming (2006) heldur pví fram að leiklist geti byggt brýr milli ólíkra einstaklinga og menningarheima í sífellt fjölbreytilegri 
nemendaflóru með pví að proska skilning, viðhorf og mismunandi gildi. Með pví að setja sig í spor annarra og spegla sig í aðstæðum peirra geta nemendur kynnst ólíkri menningu par sem peir fá tækifæri til að skoða eigin sjálfsmynd og hvernig aðrir skynja peirra veruleika. Pannig getur leiklistin líkt eftir raunverulegum heimi og gefið nemendum færi á að skoða tilfinningar sínar (Fleming, 2006). Í gegnum leiklist purfa nemendur að taka sjálfstæðar ákvarðanir og treysta eigin dómgreind. Peir purfa að vera samningaliprir og bera virðingu fyrir öðrum nemendum og umhverfi sínu (Rannveig Björk Porkelsdóttir, 2018).

Söngur og dans hefur löngum verið mikilvægur í samfélagslegum tilgangi til að efla samkennd og samstöðu par sem taugaboðefnið endorfín losnar úr læðingi (Dunbar o.fl., 2012). Í grein Helgu Rutar Guðmundsdóttur (2010), prófessors í tónlistarkennslu við Háskóla Íslands, kemur fram að ungbörn kynnist félagslegum samskiptum í gegnum tónlist jafnvel áður en pau geta tjáð sig með orðum. Hún bendir einnig á mikilvægi tónlistar við hin ýmsu tilefni par sem tónlist sameinar fólk í félagslegu samhengi. Helga segir jafnframt í grein sinni að tónlist sé manninum eðlislæg allt frá fornu fari og hafi átt pátt í að móta fólk sem manneskjur löngu áđur en tungumálið varð til. Î pví ljósi ætti tónlist að geta proskað manneskjur pvert á hina hefðbundnu tónlistarhefð. Tónlistarkennararnir Ardene Shafer og Michael Blakeslee (2000) benda á að ávinningur tónlistarnáms sé samfélagslegur og pekkingarfræðilegur auk pess sem tónlistarnám efli námsgetu og samskiptahæfni og ýti undir velgengni í lífinu. Shafer og Blakeslee (2000) segja jafnframt að rannsóknir hafi sýnt fram á að tónlistarnám hafi áhrif á proska heilans í formi aukinnar hæfni í rökhugsun. Ella Wilcox (2000), ritstjóri útgáfudeildar The National Association for Music Education, er sama sinnis og segir að tónlistarnám auki sjálfstraust og námsgetu og hafi jafnframt jákvæð áhrif á leiðtogahæfileika barna og næmi peirra. Katrina McFerran (2012), prófessor við Háskólann í Melbourne, Ástralíu, heldur pví fram að tengsl unglinga við tónlist séu mikilvægur páttur í að peir uppgötvi sjálfsmynd sína par sem peir fá tækifæri til að máta proska sinn við pær tilfinningar sem tónlistin vekur, bæði sem einstaklingar og hópur.

Samkvæmt hugmyndum danskennarans Shlomit Ofer (2015) er dans list líkamans par sem hreyfing sé tungumál tjáningar og samskipta. Auk pess geti dans verið öflugur hvati til sjálfsprottinnar tjáningar, bæði einstaklings- og félagslega. Prófessor Ann Kipling Brown (2015), við Regina-háskólann í Kanada, segir dansinn efla hugræna pjálfun í gegnum líkamann og vinnu með táknmyndir. Sheryle Bergmann (1995), prófessor við Háskólann í Manitoba, Kanada segir að oft sé litið á dans sem hluta af ípróttum í skólum. Dans snúist um að tjá hið innra sjálf, hugsanir og tilfinningar í gegnum hreyfingu sem geti styrkt sjálfstraust nemenda. Undir petta tekur Tone Østern, prófessor í dansi við Norska tækni- og vísindaháskólann (NTNU) (2015), sem bætir við að líkaminn sé hluti af fræðilegum vettvangi náms og pekkingar. Østern vill meina að menntakerfið sé ekki búið að viðurkenna pá nálgun par sem skólastofur séu enn fullar af stólum og borðum og listgreinar ekki enn orðnar kjarni allrar menntunar. Østern og Philip Channells (2016) leggja áherslu á að nemandinn taki pátt í eigin námi með gagnrýnu hugarfari og leitist við að skapa nýja pekkingu með pví að spegla hana í fyrri reynslu og pekkingu. François Victor Tochon (2010), prófessor við Háskólann í Wisconsin-Madison, er á sama máli og segir að menntun verði að byggja á verkefna- og nemendamiðuðu námi pannig að nemandinn vilji leysa verkefnin með áhuga og jákvæðni að leiðarljósi. Pannig nái nemandi að vinna verkefni af líkama og sál. Með pví að fara í gegnum skapandi ferli með dans og hreyfingu nær nemandi að vinna á dýptina. Pannig opnar hann á tilfinningar og reynslu svo að öll pekking umbreytist og nám verður til (Østern og Channells, 2016).

\section{Framkvæmd rannsóknar}

Rannsóknin byggir á eigindlegri rannsóknarhefð og fellur undir tilviksrannsókn. Eigindleg rannsóknarhefð felur í sér að safna gögnum um reynslu og upplifun peirra sem verið er að skoða ásamt að greina gögnin og túlka (Lichtman, 2013; Sigurlína Davíðsdóttir, 2003). Eigindlegar rannsóknir byggja meðal annars á viðtölum par sem unnið er út frá túlkunarhyggju (e. interpretivism) sem leggur áherslu á verufræði og reynsluheim fólks. Horft er til pess að einstaklingar séu félagslegir gerendur í eigin lífi og eigi sér sínar hugsanir, viðhorf, væntingar og prár (Helga Jónsdóttir, 2013). Í 
tilviksrannsóknum er verið að varpa ljósi á einstök tilvik, einingar eða aðstæður par sem stuðst er við athugun á vettvangi, auk viðtala, til að̈öðlast sem bestan skilning á tilvikinu. Tilviksrannsóknir leitast við að skoða hegðun, eiginleika eða einkenni einstakra hópa (Lichtman, 2013). Í pessari rannsókn var sjónum beint að einu tilviki, p.e. Skrekk, hæfileikakeppni grunnskóla Reykjavíkurborgar, og lögð megináhersla á upplifun og sýn nemenda á pátttöku í Skrekk auk viðhorfa skólastjórnenda og kennara til áhrifa verkefnisins á skólasamfélagið.

\section{Pátttakendur, gagnasöfnun og greining}

Pátttakendur í rannsókninni voru ungmenni í fimm grunnskólum á aldrinum 13-15 ára sem tóku pátt í hæfileikakeppni Skrekks haustið 2019 ásamt stjórnendum og kennurum pátttökuskóla. Auk pess tók pátt skólastjórnandi í einum skóla sem ekki var með pátttökulið í Skrekk petta árið en hafði reynslu af pátttöku frá fyrri árum. Að vori 2019 voru skrifuð bréf til skólastjórnenda grunnskóla Reykjavíkurborgar og peim skólum sem ætluðu að taka pátt í Skrekk að hausti boðin aðild að rannsókninni. Sex skólar svöruðu og var fastbundið að bjóða peim öllum til pátttöku haustið 2019. Í samráði við skólastjórnendur var ákveðið að kennari hvers Skrekkshóps myndi bjóða peim nemendum er pað vildu að taka pátt í rýnihópum rannsóknarinnar en samtals voru tekin átta rýnihópaviðtöl við nemendur. Einnig voru tekin átta einstaklingsviðtöl við kennara og stjórnendur en peir síðarnefndu höfðu milligöngu um að hafa samband við pá kennara sem tóku pátt en peir komu allir að verkefni Skrekks. Allir pátttakendur voru aðilar að rannsókninni frá upphafi til enda.

Gagnaöflun fól í sér viðtöl við pátttakendur sem henta vel sem gagnasöfnunaraðferð par sem reynsla, líðan og upplifun fólks er skoðuð. Í pessari rannsókn var notast við opin viðtöl eða djúpviðtöl sem fela í sér ferli eða flæði á milli rannsakanda og pátttakanda (Lichtman, 2013). Tekin voru viðtöl við nemendur í rýnihópum til að fá fram margvísleg viðhorf út frá sameiginlegri reynslu, tilfinningum og gildum pátttakenda gagnvart viðfangsefni rannsóknar. Rýnihópaviðtöl geta auk pess stuðlað að breidd í umræðu par sem einstaklingarnir fá stuðning hver af öðrum í gegnum félagsleg samskipti innan hópsins (Sóley S. Bender, 2013).

Öll viðtöl voru tekin upp og afrituð orðrétt par sem öllum nöfnum pátttakenda og skóla var breytt og persónueinkenni máð út (Lichtman, 2013). Við skráningu gagna var hver skóli skilgreindur með bókstaf frá A til F, til að gæta ýtrustu nafnleyndar, og hver nemandi með tölustaf frá einum upp í sjö í hverjum rýnihóp eftir fjölda nemenda í hverjum hópi.

Rannsóknin fól einnig í sér athugun á vettvangi par sem fylgst var með ungmennum á úrslitakvöldum pátttökuskóla í Borgarleikhúsinu. Rannsakendur sátu úti í sal sem óvirkir pátttakendur, fylgdust með áhorfendum úr fjarlægð og skráðu hjá sér pað sem peir heyrðu og sáu. Einnig var fylgst með pátttakendum á vettvangi hæfileikakeppninnar, baksviðs í Borgarleikhúsinu, og sama aðferðafræði notuð við skráningu gagna og hjá áhorfendum (Lichtman, 2013).

Öll gögn voru greind með opinni kóðun og lesin ítrekað, par sem leitað var eftir mynstrum og pemum. Við greiningu á gögnum var byggt á aðleiðslu. Í pví felst að rannsakandinn gerir sér í hugarlund hverjar niðurstöður geti orðið. Hann greinir og les pví í gögnin sem hann aflar og finnur mynstur og pemu sem hann dregur síðan ályktanir af og setur fram sem niðurstöður (Lichtman, 2013).

\section{Siðferðileg álitamál}

Pátttakendur fengu allir kynningu á tilgangi og markmiði rannsóknar áður en hún hófst til að geta tekið upplýsta ákvörðun um pátttöku. Einnig var pess gætt að fá upplýst og ópvingað skriflegt sampykki pátttakenda eða forráðamanna pátttakenda par sem skýrt kom fram að pátttakendur gætu hvenær sem er dregið sig út úr rannsókninni og að öllum gögnum yrði eytt að rannsókn lokinni (Sigurður Kristinsson, 2013). Par sem ungmenni áttu aðild að rannsókninni var sótt um leyfi til Skóla- og frístundasviðs Reykjavíkurborgar og upplýsingar sendar Vísindasiðanefnd HÍ til umsagnar, 
sem ekki gerði athugasemd. Jafnframt var sent kynningarbréf til foreldra peirra ungmenna sem tóku pátt par sem peir voru beðnir að sampykkja pátttöku barna sinna í rannsókninni. Leitast var við að gera ungmenni rannsóknarinnar að fullgildum pátttakendum par sem hlustað var á sjónarmið peirra og reynslu samkvæmt siðareglum HÎ í rannsóknum og pau beðin að skrifa undir upplýst og ópvingað sampykki fyrir rannsókninni par sem fyllsta trúnaði var heitið. Par sem rannsóknin er takmörkuð við einstakt tilvik getur reynst erfitt að leyna pví í litlu samfélagi eins og hér á landi hvaða skóla er fjallað um. Pví voru öll gögn gerð ópersónugreinanleg (Vísindasiðareglur Háskóla Íslands, 2014) og vísbendingar um nöfn skóla eða pátttakenda fjarlægð úr beinum tilvitnunum.

\section{Niðurstöður}

Hér verður greint frá helstu niðurstöðum rannsóknarinnar og vísað í viðtölin peim til stuðnings. Settir voru fram prír efnisflokkar sem voru lýsandi fyrir gögnin: 1) Reynslunám. 2) Lýðræði; undirpemu fyrstu tveggja efnisflokkanna eru félagsleg tengslamyndun og sjálfsefling. 3) Áhrif listgreina á skólasamfélagið.

\section{1) Reynslunám}

Pátttakendur lýstu upplifun sinni og reynslu af pátttöku í Skrekk sem peir töldu vera valdeflandi pátt í námi par sem pátttaka hefði verið jákvæð og uppbyggjandi í gegnum félagsleg tengsl auk pess að hafa áhrif á skólasamfélagið í heild sinni. Í viðtölum kom fram að nemendur upplifðu sterkari félagstengsl með pví að eiga í nánari og persónulegri kynnum við samnemendur. Peir voru meðal annars ófeimnari að ræða við samnemendur á göngum skólans og porðu frekar að viðra hugmyndir sínar innan Skrekkshópsins og tala um hvernig peim liði. Peir kynntust á annan og nánari hátt en í kennslustundum par sem hin „hefðbundnu“ bóklegu fög eru kennd. „... Petta er ógeðslega gaman og pú kynnist krökkunum, sem pú ert alltaf með á hverjum degi, sem pú pekktir ekkert." Nemendur voru einnig sammála um að pessi reynsla skapaði dýrmætar minningar til framtíðar eins og einn nemandinn lýsti á eftirfarandi hátt: „Petta eru líka öll árin sem við munum muna eftir.“ Pað kom einnig skýrt fram að nemendur sáu tækifæri í að kynnast mismunandi einstaklingum og hópum til framtíðar og efla félagstengsl sín pvert á árganga; peir upplifðu petta sem mjög mikilvægan pátt í ferlinu:

Pað er nefnilega pað sem er svo skemmtilegt við Skrekk, við getum tengt við til dæmis 06 [ungmenni fædd árið 2006] sem enginn í tíunda bekk er eitthvað mikið í samskiptum við. Núna getum við tengt við pau og á göngunum getum við sagt hæ við pau og svona, í staðinn fyrir að petta sé svona tíundi bekkur einn, áttundi einn og svo níundi. Pannig að petta er svona meira samfélag, öll að tengja meira hvert við annað.

Nemendur upplifðu einnig mikla samstöðu í vinnu sinni varðandi Skrekk eins og fram kom hjá einum nemandanum: „Раð eru allir bara að styrkja hver annan og halda með hver öðrum. Og hugsa ekki bara um sjálfa sig, líka hina." Annar pátttakandi talaði einnig um mikla samstöðu milli pátttökuskóla par sem hann lýsti jákvæðu andrúmslofti og liðsheild: „Já, pau eru öll svona saman. Ég man líka pegar skóli $C$ var að sýna pá voru allir að gera petta á meðan allir hjá okkur voru að gera svona. Allir voru saman í pví. Petta tengir eiginlega alla saman."

Í hópviðtali við ungmennin kom fram að pau upplifðu mikla gleði, traust og samkennd. Náin tengsl innan hópsins gegna stóru hlutverki í vinnunni í Skrekk ef vel á að takast til par sem allir verða að vinna saman á uppbyggjandi hátt að sameiginlegu atriði: „Ég tók pátt í fyrra og mér fannst pað ógeðslega gaman og ég varð nánari með öllum krökkunum og svona og pað var gaman að koma saman og sjá alla hæfileikana hjá öllum og setja petta saman og svona.“

Nemendur greindu einnig frá tilfinningalegri samstöðu sem gerði pað að verkum að peir voru óhræddari við að opna á tilfinningar sínar og prófa sig áfram án pess að vera dæmdir fyrir pað. Peir porðu frekar að gera mistök og takast á um ólíkar hugmyndir pví að ef einhver var stressaður kom 
alltaf einhver til peirra og knúsaði og hvatti áfram: „... Раð hafa allir grátið saman og allir hlegið saman og allir verið reiðir og pirraðir saman og allir gert pað sama“. Einn nemandinn komst svo аð orði: „Баð myndast svona Skrekksfjölskylda. Рað er alveg rosalega mikið traust í pessu.“ Annar nemandi bætti við: „... Af pví að ég er mjög lokuð manneskja og með Skrekksatriði, pað hjálpaði mér að tala meira og tala um hvernig mér líður við alla ...". Nemendur lærðu að treysta hver öðrum í gegnum vinnuferlið sem efldi samvinnu peirra og jákvætt viðhorf til verkefnisins, sjálfs sín og ekki síður til hver annars. Með samkennd og jákvæðu viðhorfi náðu nemendur sameiginlegu markmiði með pví að leggja sig fram og sigrast á fyrirstöðum, hver með sínum hætti.

Í viðtölum við nemendur kom einnig fram að pátttaka í Skrekk hafði áhrif á sjálfstraust peirra og sjálfsmynd. Peir sögðu að pátttakan byggði upp sjálfstraust og sjálfsmynd peirra. Einn nemandinn sagði:

Maður svona byggir eiginlega svona sjálfstraust eða svona sjálfsmyndina sína, meira og meira upp. Petta hjálpar manni svona, pegar pú ert á sviði pá ertu ótrúlega stressaður en pegar pú ferð svo út pá ertu bara ógeðslega ánægður með pig og ert bara vá, petta átti að vera ógeðslega gott atriði og petta var bara gott atriði!

Af framangreindu má sjá að pátttaka í Skrekk efldi traust og samkennd nemenda og hafði jákvæð áhrif á sjálfstraust peirra og sjálfsmynd. Gagnkvæmt traust getur pannig verið ein af forsendum velsældar og sjálfseflingar. Pátttaka í Skrekk styrkti nemendur á margan hátt par sem peir fengu tækifæri til að máta sig við félaga sína, sjálfsmynd peirra batnaði og sjálfstraustið fór vaxandi.

\section{2) Lýðræði}

Pátttakendur lýstu hversu lærdómsríkt pað hefði verið að vinna með öðrum í stórum hópi par sem gildi lýðræðis voru höfð að leiðarljósi. Í rýniviðtölum kom fram að ungmennin upplifðu íhlutun í eigin námi par sem skipst var á skoðunum og miklar umræður fóru fram um atriði hópsins. Einn nemandinn sagði: „Við ræðum mjög mikið og svona hugsum geðveikt mikið. Ræðum mjög mikið hvernig við viljum að atriðið verði ef við komum með hugmyndir og síðan veljum við bara." Greinilegt er að mikil áhersla var á samvinnu og samtal í Skrekkshópunum. Pað var mikið lagt upp úr pví að nemendur tækju tillit til mismunandi skoðana og lærðu að hlusta hver á annan af virðingu áður en komist var að niðurstöðu um innihald atriðisins og útfærslu. Peir töluðu líka um að allir yrðu að vera rólegir eins og einn nemandi sagði:

Petta tekur tíma og maður parf að geta, pegar maður er með sínar skoðanir og vill tjá sig, maður hefur alveg rétt til pess en svo pegar einhver er ekki sammála pá purfum við að tækla pað og pá purfa allir að vera rólegir af pví að petta tekur tíma. Lögð var áhersla að hver og einn kæmi með sínar skoðanir og hugmyndir og síðan var hægt að bæta inn í og taka út og pannig.

Misjafnt var hvernig unnið var að hugmyndavinnu atriðis Skrekks. Í einum skóla mynduðu nemendur mismunandi hópa eftir áhugasviði og hugmyndum og æfðu sitt atriði í tiltekinn tíma. Pegar pví var lokið voru öll atriðin kynnt og besta atriðið kosið par sem kennari og jafnvel utanaðkomandi aðili, sem oft var fyrrverandi Skrekksmeðlimur, völdu bestu hugmyndina. Síðan var sú hugmynd útfærð nánar af öllum hópnum og endaði á sviði Borgarleikhússins. Aðrir skólar lögðu áherslu á að vinna með öllum hópnum, saman, frá upphafi par sem byrjað var á að velta upp ýmsum hugmyndum um innihald atriðis. Nemendur spunnu síðan út frá hugmyndunum og sýndu samnemendum sínum afraksturinn. Útkoma spunanna var síðan rædd og vegin í kjölfarið. Eftir pessa hugmynda- og spunavinnu kusu nemendur bestu hugmyndina sem var útfærð nánar og æfð fyrir keppnina. Einnig var sú lausn fengin hjá enn öðrum skólum, ef margar góðar hugmyndir fóru saman, að reyna að finna sameiginlegan flöt á nokkrum hugmyndum. Pær hugmyndir voru síðan sameinaðar í eitt atriði sem síðan var útfært og æft áfram eins og einn nemandi lýsti pví svo vel: „Đað voru eiginlega svona prjár hugmyndir sem var blandað saman. Við kusum fyrst en svo virkaði pað ekki alveg pannig að við ákváðum svona eiginlega bara að blanda pessu saman." 
Í viðtölum var nemendum tíðrætt um gleðina sem einkenndi vinnuna í Skrekk par sem allir voru að vinna að sameiginlegu markmiði. Ungmennin fundu jafnframt til ábyrgðar og stolts að vera sjálf við stjórnvölinn par sem pau sömdu atriðið sitt sjálf og purftu pannig að standa og falla með eigin ákvörðunum og gjörðum í gegnum allt vinnuferlið eða eins og fram kom hjá einum nemandanum: „Petta er ógeðslega gaman. Bara hópefli eða svona hópsamvinna er geggjað gaman. Og pað er líka gaman að vera með hugmynd og sjá hana gerast."

Nemendum póttu yfirleitt sjálfsögð og eðlileg lýðræðisleg vinnubrögð sem byggja meðal annars á virkni og virðingu par sem ólíkir einstaklingar mynda tengsl og læra hver af öðrum, eða eins og nemandi sagði: „Рað var lögð mikil áhersla á að hver og einn kæmi með sínar skoðanir og hugmyndir og síðan var hægt að bæta inn í og taka út og pannig.“ Annar nemandi bætti við: „Já, skipta okkur í svona hópa og við vorum svona að ,brainstorma ' hvaða hugmyndir við vildum gera. Svo kom bara ein hugmynd og svo vorum við bara að próa hana."

Eins og fram kemur hér að ofan einkenndist vinnuferlið af mikilli samvinnu og virðingu á jafnréttisgrundvelli par sem hlustað var á raddir allra og nemendur purftu að lokum að komast að sameiginlegri niðurstöðu pó að pað gæti tekið tíma og reynt á polinmæðina eins og áður segir. Nemendur, bæði sem einstaklingar og hópur, eflast og fyllast orku pegar peir upplifa að hlustað sé á pá og ákvarðanir teknar á jafnréttisgrundvelli eins og fram kom í vettvangsathugun rannsakenda á úrslitakvöldi Skrekks: „एað er greinilega mikil spenna í loftinu og nemendur fullir tilhlökkunar að fá að standa á stóra sviði Borgarleikhússins. Nemendur hlaupa upp og niður stigana af ópreyju og gleði.“

\section{3) Áhrif listgreina á skólasamfélagið}

Pegar áhrif listgreina á skólasamfélagið eru skoðuð má sjá að bæði nemendur og kennarar litu á pátttöku nemenda í Skrekk sem ávinning fyrir allt skólasamfélagið, par sem nemendur á unglingastigi taka beinan og óbeinan pátt, annaðhvort sem pátttakendur eða stuðningsaðilar. Eins purftu pátttakendur í Skrekk að vinna saman pvert á árganga og töldu kennarar listirnar efla skapandi hugsun nemenda par sem efniviðurinn væri í stöðugri próun. Einn kennarinn sagði:

Ég tel pað [pátttöku í Skrekk] hafa mjög jákvæð áhrif. Aðallega hvað ferli varðar pá myndar pað svona samvinnu og pau kynnast á milli árganga, pau temja sér svona ákveðna ábyrgðartilfinningu og vinnu, samvinnuhæfni, sem bara dreifist svo út í hópinn sem slíkan. Pað myndast svona stemning fyrir pessu.

Nemendur fá tækifæri til að skoða efni út frá ólíkum sjónarhornum með pví að prófa mismunandi hugmyndir í æfingaferlinu. Peir fá að vinna með hugmyndir sínar og purfa að hlusta og vinna með hugmyndir annarra. Peir skoða fleiri en eina lausn á hverju viðfangsefni par sem ekkert eitt svar er endilega réttara en annað. Skólastjórnandi sagði:

Ég held að Skrekkur sé tækifæri fyrir unglingana til að vinna á annan hátt en almennt skólastarf. Ég held að pað sé tækifæri til pjálfunar í félagsfærni og frumkvæði og sköpun, eitthvað sem mætti vera meira af í skólastarfi.

Pátttaka í Skrekk gengur út á samvinnu og lýðræðisleg vinnubrögð í gegnum listir. Samkvæmt kennara er aðalávinningur Skrekks tengslin sem myndast á milli áttunda, níunda og tíunda bekkjar og vinátta, jafnvel eftir að nemandi útskrifast. Með pátttöku í Skrekk ná nemendur að tengjast á annan hátt en peir gera í valgreinum. Eins og fram kom hjá kennara hefur pátttakan áhrif út í skólasamfélagið, jafnt á ganginum eða úti í frímínútum. „Pá eru allt í einu einhver úr áttunda bekk og einhver úr tíunda bekk ágætis vinir af pví að pau hafa verið saman í pessu fagi. Pað skapast öðruvísi stemning heldur en í smíði eða myndmennt. Pau verða félagar á annan hátt.“ „Рað er óhætt að segja að Skrekkur sé í grunninn bara ein stór lífsleiknisprengja," sagði einn kennari. Í flestum pátttökuskólum er hefð fyrir pví að sýna Skrekksatriðið fyrir alla nemendur skólans auk pess sem nemendur skólanna eiga pess kost að koma á úrslitakvöldin til að styðja sinn skóla. Pátttöku í Skrekk fylgir oft mikil gleði og ánægja. „Pau fóru heim úr leikhúsinu með pað í augunum að pau unnu 
Skrekk“. Nemendur ræddu atriði við kennara sinn pegar pau komu af sviði og pau fundu hvað salurinn tók vel við og hló og pað var gleði, pau fundu að pau unnu salinn.

Stjórnendur og kennarar töldu aðild að Skrekk, hvort heldur í formi pátttakenda eða áhorfenda, mjög mikilvæga fyrir nemendur til að tengjast og kynnast listviðburðum í samfélagi sínu og peir lögðu áherslu á að efla listkennslu og sköpunarkraft nemenda. Peir kynntust pví líka að upplifa hlutina á annan hátt sem áhorfendur að öðrum listviðburðum. Einn kennari tók undir mikilvægi pess að allir nemendur, hver sem bakgrunnur peirra væri, kynntust samfélagi sínu í gegnum menningarviðburði, leikhús og listir.

Pað hefur áhrif á skólasamfélagið að með starfi í Skrekk kynnast nemendur á annan hátt en í hefðbundnum kennslustundum og með pví að horfa á leikatriði, hvort heldur í Borgarleikhúsinu eða í skólanum. Peir sem vilja, fylgjast með af áhuga og forvitni auk áhorfenda sem flykkjast í Borgarleikhúsið til að styðja sinn skóla. Í vettvangsathugun rannsakenda kom fram að mikil spenna lá í loftinu á úrslitakvöldi Skrekks: „Áhorfendur hafa komið sér fyrir með hvatningarspjöld og í mismunandi litum bolum eftir skólum. Pað eru mikil læti og áhorfendur keppast við að kalla hvaða skóli er bestur."

Af framangreindu má ljóst vera að pátttaka skóla í Skrekk hefur áhrif á skólasamfélagið í heild sinni. Par er samkennd, samtakamætti og hvetjandi hugarfari gert hátt undir höfði. Nemendur vinna pvert á árganga að sameiginlegu markmiði sem gerir samskipti lipurri og jákvæðari.

\section{Samantekt og umræða}

Listgreinarnar auka skilning fólks á heiminum og geta breytt ríkjandi hugmyndafræði (Fleming, 2012). Listir eru umbreytandi á marga vegu par sem efniviðurinn er í stöðugri próun (Anderson, 2012; Neelands, 2015; Rannveig Björk Porkelsdóttir, 2016). Í gegnum hugmyndafræði listgreina verður til aukin pekking, reynsla og skilningur á pví samfélagi sem fólk býr í. Að auki eflir listsköpun innri ánægju, ásamt pví að auka lýðræðisvitund og gagnrýna hugsun. Markmið pessarar greinar er að stuðla að aukinni pekkingu á listkennslu og kanna hvaða áhrif aðild að verkefni eins og Skrekk hefur á líðan og sjálfsmynd ungmenna, auk pess að skoða hvaða áhrif pátttaka hefur á skólabrag og skólamenningu.

Niðurstöður sýna að pátttakendur í Skrekk upplifðu verkefnið sem valdeflandi pátt í námi sínu í gegnum félagsleg tengsl par sem pátttaka var bæði jákvæð og uppbyggjandi. Petta samræmist kenningu Deweys (2000) sem bendir á að menntun sé félagslegt ferli sem byggi á jákvæðri reynslu auk pess sem nemendur eflist pegar peir taka pátt í eigin námi par sem reynsla peirra er metin að verðleikum. Østern og Channells (2016) taka undir og telja að menntun verði að vera djúp upplifun par sem nemandinn eigi aðild að eigin námi með gagnrýnu hugarfari og reyni að skilja nýja pekkingu út frá fyrri reynslu.

Með pátttöku í Skrekk upplifðu nemendur hvernig peir kynntust samnemendum sínum, pvert á árganga, á nánari og persónulegri hátt par sem dýrmætar minningar og jafnvel ný vinatengsl urðu til. Peir upplifðu einnig að samskipti urðu auðveldari og ópvingaðri á göngum skólans. Pað samræmist O’Neill (2013) og Anderson (2012) sem telja listirnar eflandi og hvetjandi pátt í námi sem auki forvitni og sköpunarkraft og efli færni til samvinnu og samskipta til framtíðar.

Rannsókn Rannveigar Bjarkar Porkelsdóttur (2016) sýndi fram á að hver hópur ungmenna setur sínar eigin reglur og viðmið sem endurspeglar hegðun peirra og viðhorf. Hver einstaklingur mátar sig innan síns hóps og í gegnum hópvitundina proska einstaklingar með sér hæfni til að geta tjáð sitt félagslega sjálf. Pað var áberandi hversu miklar breytingar pátttakendur upplifðu á líðan og samskiptum í formi trausts með pátttöku sinni í Skrekk par sem samkennd var áberandi páttur. Neelands (2015) og Anderson (2015) benda á að listir geti haft breiða skírskotun í formi umbreytinga á lífi fólks og samfélagi og Rannveig Björk Porkelsdóttir (2016) bætir við að nemendur í leiklist 
proski tilfinningar sínar með samkennd og sjálfsstjórn sem efli félagslega hæfni peirra og samvinnu. Pannig eru nemendur reiðubúnari til að hlusta og hvetja hver annan til dáða, meðal annars í hugmyndavinnu og útfærslu verkefnis. Flestir viðmælendur nefndu að pað hefði verið jákvæð reynsla og auðveldara en peir héldu að deila hugmyndum sínum innan hópsins, jafnframt pví að hlusta á hugmyndir annarra, par sem peir náðu að spegla og skerpa eigin sýn og annarra á jákvæðan hátt í traustu umhverfi. Pessar niðurstöður eru í samræmi við kenningar Eisners (2002) sem segir eðli lista vera að skoða efni út frá ólíkum sjónarhornum par sem líkami og hugur nemenda er virkjaður til að kanna hvernig viðfangsefni raðast saman. Fleming (2012) heldur pví fram að listir auki skilning á heiminum par sem pær víkki sjóndeildarhring fólks og ríkjandi hugmyndafræði. Með listsköpun verða til tækifæri til að rannsaka og meta listir frá mörgum sjónarhornum svo að til verði aukin pekking í gegnum reynslu og skilning. Kenningar Neelands (2015) undirstrika pessar niðurstöður en hann leggur áherslu á að listir séu kröftug leið til að takast á við reynslu sína, auk pess sem pær efli velsæld og seiglu ásamt félagslegri samheldni.

Vinnuferlið í Skrekk einkenndist af lýðræði par sem áberandi pættir voru samvinna, jafnrétti, virkni, skapandi hugsun, hlustun, gagnkvæm virðing og viðurkenning ásamt réttlæti, gagnrýninni samræðu, pátttöku og jafnrétti (sjá Ólaf Pál Jónsson og Póru Björgu Sigurðardóttur, 2012). Óhætt er að segja að miklar umbreytingar eigi sér stað hjá pátttakendum í Skrekk í formi jákvæðrar upplifunar. Peir eflast við samvinnu og uppbyggilegar samræður par sem skoðanaskipti á jafnréttisgrunni eru í hávegum höfð. Skapandi hugmyndir verða til með miðlun sem endurnýjast um leið. Petta samræmist hugmyndum Neelands (2015) og Andersons (2015) sem segja listirnar vera umbreytandi á marga vegu par sem efniviðurinn tekur stöðugt breytingum. Hugmyndir umbreytast í veruleika, samvinnan umbreytir peim manneskjum sem taka pátt, par sem veruleikinn er dreginn í efa og endurhugsaður. Pannig á sér stað félagsleg umbreyting í gegnum listir.

Pátttaka í Skrekk sýndi fram á að vinátta og náin félagsleg tengsl sem myndast, pvert á árganga, geri pað að verkum að öll samskipti á göngum og í skólastofum verða auðveldari par sem sameiginlegur skilningur og virðing myndast meðal nemenda. Petta samræmist rannsókn Rannveigar Bjarkar Porkelsdóttur (2016) sem gaf til kynna að pátttaka nemenda í leiklist væri ávinningur fyrir allt skólasamfélagið par sem ólíkir einstaklingar ynnu saman og listirnar hefðu eflandi og skapandi áhrif á hugsun nemenda.

\section{Áhrif pátttöku í Skrekk á skólasamfélagiò}

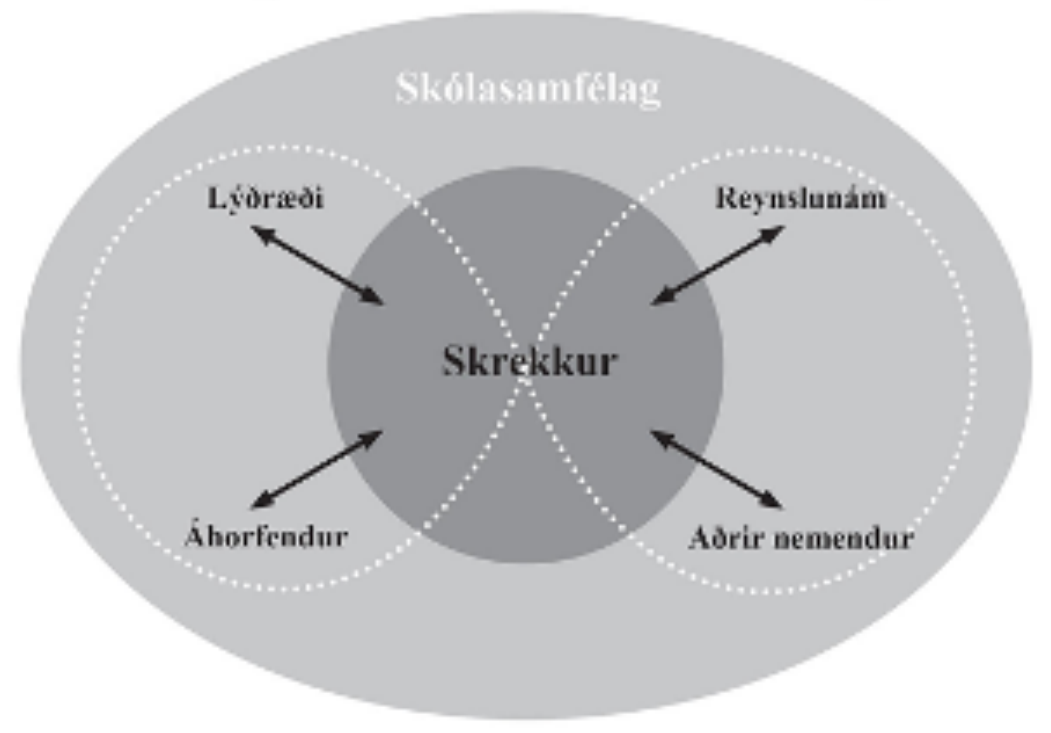

Mynd 1. Áhrif pátttöku í Skrekk á skólasamfélagið.

(C) Jóna Guðrún Jónsdóttir, 2020 
Aðild að Skrekk jók á stolt nemenda, bæði pátttakenda og áhorfenda pátttökuskóla, svo og peirra nemenda sem fylgdust með úr fjarlægð. Pannig urðu bæði pátttakendur og áhorfendur hluti af Skrekkssamfélaginu (sjá Mynd 1). Ætla má að pátttaka í Skrekk hafi pannig jákvæð áhrif á viðhorf og nám nemenda í skólanum. Einnig má ætla að sú samkennd og pað hvetjandi hugarfar sem nemendur tileinka sér í Skrekk geti smitað út frá sér til skólasamfélags í heild sinni. Pað er í takt við kenningar Flemings (2006) sem bendir á að listirnar geti haft jákvæð áhrif á menningu innan skóla par sem pær hafi breiða skírskotun í formi umbreytinga á lífi fólks og samfélagi. Par sem listir eru í boði sé viðhorf nemenda jákvæðara en ella sem geti aftur haft áhrif á almenna hæfni nemenda í námi. Auk pess má segja að með pátttöku í Skrekk upplifi bæði pátttakendur og áhorfendur sameiginlega reynslu leikhússins og listarinnar og sái pannig fræjum sem hugsanlega eiga eftir að blómstra. Fleming (2006) bendir enn fremur á mikilvægi pess að menntun byggi ekki einungis á pví sem námskráin hefur að bjóða, heldur birtist ekki síður í að skapa jákvæða menningu innan skólans. Sýnt hafi verið fram á að par sem boðið sé upp á mikla listkennslu sé viðhorf nemenda jákvæðara, og pað hafi aftur áhrif á almenna hæfni peirra.

\section{Lokaorð}

Niðurstöður sýna að pátttakendur í Skrekk upplifðu verkefnið sem valdeflandi pátt í námi sínu. Pátttaka í verkefninu var bæði jákvæð og uppbyggjandi og efldi félagsleg tengsl. Nemendur kynntust hverjir öðrum, pvert á árganga. Pau jákvæðu tengsl og pað uppbyggjandi andrúmsloft sem myndaðist innan hvers Skrekkshóps gerði pað að verkum að nemendur áttu auðveldara með að tjá sig á áreynslulausan hátt og hlusta af virðingu og gagnkvæmu trausti á samnemendur sína. Pátttakendur áttu auðveldara með að deila hugmyndum sínum og skoðunum. Eins náðu peir að aðstoða hver annan á valdeflandi hátt. Virðing gagnvart verkefninu og ekki síður einstaklingum innan hópsins var áberandi páttur í öllu ferlinu. Nemendur litu á sjálfsákvarðanatöku sem eflandi pátt í vinnuferlinu. Peir upplifðu að peir væru við stjórnvölinn og bæru sjálfir ábyrgð á námi sínu. Nemendur uppgötvuðu nýjar hliðar á sjálfum sér og áttu auðveldara með að skoða og deila tilfinningum sínum. Með samvinnu og gagnkvæmri hlustun fannst peim peir öðlast nýja reynslu og nýja sýn á sjálfa sig og aðra. Peir upplifðu aukinn proska og sjálfstraust með aukinni velsæld og sjálfseflingu sem eru mikilvægir pættir í að styrkja sjálfsmynd peirra. Nemendur upplifðu jöfn tækifæri til skoðanaskipta. Peir voru mjög meðvitaðir um réttlæti og jafnræði par sem allir fengu tækifæri til að láta rödd sína heyrast. Pau félagslegu tengsl sem peir mynduðu í Skrekksverkefninu höfðu áhrif á skólasamfélagið í heild sinni. Peir störfuðu pvert á árganga og kynntust innbyrðis. Samskipti á göngum skólans urðu afslappaðri og pað skapaðist sameiginlegur skilningur og virðing meðal nemenda. Á pann hátt urðu listirnar páttur í reynslunámi nemenda. Pessi rannsókn er innlegg í áframhaldandi rannsóknir og munu höfundar halda áfram að skoða áhrif Skrekks á skólasamfélagið út frá fleiri sjónarhornum en hér er gert.

\section{Pakkir}

Rannsóknin sem greinin byggir á er styrkt af Rannsóknasjóði Háskóla Íslands og fær hann pakkir fyrir. 


\section{Time to remember: Students benefit from participation in Skrekkur, a talent competition for lower secondary schools in Reykjavík.}

The aim of this article is to shed light on how participation in projects such as Skrekkur, a talent competition for lower secondary schools in Reykjavík, affects the well-being and self-image of young people. The article will also attempt to clarify the nature of arts education among 13-15 year old students and explain the effect of a project such as Skrekkur on the school community and wider society. The article builds on Jóna Guðrún Jónsdóttir's M.Ed. thesis How to wake up the arts in oneself. There has been a major change in education in Iceland in recent decades. The education policy published in the National Curriculum for Compulsory Schools from 2013 emphasizes six fundamental pillars of education; that is, literacy, sustainability, health and wellbeing, democracy and human rights, equality and creativity. Among other things, the curriculum states: "Compulsory school should develop students' skills in the spirit of the six fundamental pillars and prepare them for participation in a democratic society" (Mennta- og menningarmálaráðuneyti, 2013). The arts make a strong claim to being part of the educational system. Through the arts, students can construct aesthetic knowledge and deepen their human impulses and human experiences. Through drama, dance and music young people gain the opportunity to perform seven minutes of production in Skrekkur, a talent competition for lower secondary schools in Reykjavík which a group of 35 students have created as their own from beginning to end. The project is a cooperative venture of the compulsory school and the Reykjavík Municipality Department of Recreation and Youth. This venture is created for the benefit of the young people themselves and also in support of the school community and wider society. The goal of the project is, among other things, to practice cooperation, strengthen self-esteem and compassion, and broaden horizons. Through drama, dance and music the students can learn to interact with one another in a safe space and try out different societal roles. Through role play students have the opportunity to explore aspects of what it means to be human, democracy and critical thinking through experiential learning. Studying through the arts teaches students to express themselves in a different way than going by the book. Andersen (2012), Neelands (2015) and Rannveig Björk Porkelsdóttir (2018), believe that drama is a mode of transformative learning. The research sets out to discover how participation in Skrekkur affects young people's well-being and self-esteem in compulsory education in Reykjavík. The overarching research questions are: How does participation in Skrekkur affect young people's well-being? How does participation in Skrekkur affect the students' self- esteem? What is the impact of participation on the school community and school culture? An ethnographic study was carried out within a socio-cultural framework of understanding. Interviews were conducted in seven compulsory schools in Reykjavík, with students, teachers and headmasters under participants' observation. The results showed that participation in Skrekkur positively affects the wellbeing and self-image of young people, especially when they are given the opportunity to work from their own experience of education and democratic values. The study also showed that participation in Skrekkur benefits the school community, as strong team unity formed around the competition. Students got to know other students from different year classes and it turned out that they regarded their participation as a very valuable time resulting in positive memories. Participation increased the students' self-pride; this applied both to the participants and spectators from the participating schools as well as to students who watched by distance. Thus, participants and spectators became part of the Skrekkur community, where social bonds were formed, as well as cultural and social influences that supported the school community as a whole. In this way, the arts became part of the students' experiential learning.

Key words: Arts education, drama education, experiential learning, democracy, school culture 


\section{Um höfundana}

Jóna Guðrún Jónsdóttir (jonag@hi.is) er aðjúnkt við Menntavísindasvið Háskóla Íslands. Hún lauk kennsluréttindanámi frá HÍ árið 2005 og meistaragráðu í kennslu listgreina 2020. Jóna Guðrún hefur um 20 ára kennslureynslu á öllum skólastigum. Hún hefur sérhæft sig í leiklistarkennslu og áhrifum leiklistar í tengslum við nám barna. Rannsóknarsvið hennar tengist meðal annars listkennslu, fjölmenningu og leiklist.

Rannveig Björk Porkelsdóttir (rbth@hi.is) er dósent við Menntavísindasvið Háskóla Íslands. Hún lauk B.Ed.-prófi frá Háskóla Íslands árið 2003, M.A.-prófi í uppeldis- og menntunarfræðum frá sama skóla árið 2009 og M.A. prófi í hagnýtri menningarmiðlun frá sagnfræði- og heimspekideild árið 2012. Hún lauk doktorsprófi frá Kennaradeild Norska tækni- og vísindaháskólans, (NTNU) í Prándheimi 2016 par sem hún skrifaði um innleiðingu leiklistar í grunnskóla á Íslandi. Rannsóknarsvið Rannveigar tengist meðal annars listkennslu og leiklist.

\section{About the authors}

Jóna Guðrún Jónsdóttir (jonag@hi.is) is an adjunct lecturer at the University of Iceland, School of Education. She completed her teaching qualification from the University of Iceland in 2005 and an M.Ed. in Arts Education, also from the University of Iceland, in 2020. Jóna Guðrún has about 20 years of teaching experience at all school levels. She has specialized in Drama Education and the impact of drama in relation to children's learning. In her research and practice she focuses on drama and artistic approaches to teaching and learning as well as multiculturalism.

Rannveig Björk Thorkelsdóttir (rbth@hi.is) is an associate professor at the University of Iceland, School of Education. She completed her B.Ed. degree from the University of Iceland in 2003, an M.A. degree in Educational Theory in 2009 and an M.A. degree in applied studies in Culture and Communication from the University of Iceland Faculty of History and Philosophy in 2012. She holds a Ph.D. from the Norwegian University of Science and Technology (NTNU) with emphasis on drama and theatre study. In her research and practice she focuses on drama and artistic approaches to teaching and learning.

\section{Heimildir}

Anderson, M. (2012). Masterclass in drama education. Transforming, teaching and learning. New York: Bloomsbury.

Anderson, M. (2015). Drama, creativity and learning. Í S. Schonmann (ritstjóri), International yearbook for research in arts education (bls. 235-240). New York: Waxmann.

Bergmann, S. (1995). Creative dance in the education curriculum: Justifying the unambiguous. Canadian Journal of Education / Revue canadienne de l'éducation, 20(2), 156-165. Sótt af https:/www.jstor.org/stable/1495274?seq=1\#metadata_info_tab_contents

Brown, A. K. (2015). Why teach dance notation? Í S. Schonmann (ritstjóri), International yearbook for research in arts education (bls. 119-123). New York: Waxmann.

Dewey, J. (1916). Democracy and Education. Gutenberg. Sótt af https://www.gutenberg.org/files/852/852h/852-h.htm

Dewey, J. (2000). Reynsla og menntun (Gunnar Ragnarsson pýddi). Reykjavík: Rannsóknarstofnun Kennaraháskóla Íslands. 
Dunbar, R. I. M., Baron, R., Frangou, A., Pearce, E., van Leeuwen, E. J. C., Stow, J., Partridge, G., . . van Vugt, M. (2012). Social laughter is correlated with an elevated pain threshold. Royal Society of London. Series B, biological sciences, 279(1731), bls. 1161-1167. doi:10.1098/rspb.2011.1373

Eisner. E. W. (2002). The arts and the creation of mind. New Haven \& London: Yale University Press.

Fleming, M. (2006). Justifying the arts: Drama and intercultural education. The Journal of Aesthetic Education, 40(1), 54-64. Sótt af https://www.jstor.org/stable/4140217?seq=1\#metadata_info_tab_contents

Fleming, M. (2012). The arts in education. An introduction to aesthetics, theory and pedagogy. London: Routledge.

Helga Rut Guðmundsdóttir. (2010). Hugmyndir um uppruna tónlistar í ljósi pekkingar af vettvangi heilarannsókna og tónlistarrannsókna. Ráðstefnurit Netlu - Menntakvika 2010. Sótt af http://netla.hi.is/menntakvika2010/alm/014.pdf

Helga Jónsdóttir. (2013). Viðtöl í eigindlegum og megindlegum rannsóknum. Í Sigriłður Halldórsdóttir (ritstjóri), Handbók i aðferðafraði rannsókna (bls. 137-153). Akureyri: Háskólinn á Akureyri.

Jóhanna Einarsdóttir. (2010). Reynsla og nám barna. Í Jóhanna Einarsdóttir og Ólafur Páll Jónsson (ritstj.), John Dewey i hugsun og verki. Menntun, reynsla og lýdraði. Reykjavík: Heimspekistofnun Háskóla Íslands

Lichtman, M. (2013). Qualitative research in education: User's guide (3. útgáfa). London: Sage.

McFerran, K. (2012). Music and adolescents. Í N. S. Rickard og K. McFerran (ritstjórar), Lifelong engagement with music. Benefits for mental health and well-being (bls. 97-108). London: Nova Science Publishers.

Mennta- og menningarmálaráðuneyti. (2013). Aðalnámskrá grunnskóla: Almennur hluti 2011: Greinasvið 2013. Reykjavík: Höfundur.

Neelands, J. (2015). Art makes children powerful: Art for the many not the few. Í M. Fleming, L. Bresler og J. O'Toole (ritstjórar), The Routledge international handbook of the arts and education (bls. 410-417). London: Routledge.

Ofer, S. (2015). Movement literacy: Implementing dance notation studies into educational dance curriculum. Í S. Schonmann (ritstjóri), International yearbook for research in arts education (bls. 124-128). New York: Waxmann.

O’Neill, C. (2013). Foreword. Í M. Anderson og J. Dunn (ritstjórar), How drama activates learning. Contemporary research and practice (xix-xxi). London: Bloomsbury.

Ólafur Páll Jónsson. (2010). Hugsun, reynsla og lýðræði. Í Jóhanna Einarsdóttir og Ólafur Páll Jónsson (ritstj.), John Dewey i hugsun og verki. Menntun, reynsla og lýdraði. Reykjavík: Heimspekistofnun Háskóla Íslands.

Ólafur Páll Jónsson. (2011). Lýdraði, réttlati og menntun. Hugleiðingar um skilyrði mennskunnar. Reykjavík: Háskólaútgáfan.

Ólafur Páll Jónsson og Póra Björg Sigurðardóttir. (2012). Lýðraði og mannréttindi, grunnpáttur menntunar á öllum skólastigum. Reykjavík: Mennta- og menningarmálaráðuneytið og Námsgagnastofnun.

Rannveig Björk Porkelsdóttir. (2016). Understanding drama teaching in compulsory education in Iceland (doktorsritgerð). Prándheimur: Norwegian University of Science and Technology,

Rannveig Björk Porkelsdóttir. (2018). Margbrotið hlutverk leiklistarkennarans í kennslu leiklistar í tengslum við innleiðingu á leiklist. Sérrit Netlu - Bókmenntir, listir og grunnpattir menntunar. Sótt af http://netla.hi.is/ serrit/2018/bokmenntir_listir_menntun/07.pdf

Shafer, A. og Blakeslee, M. (2000). Talking points. Í A. Shafer og M. Blakeslee (ritstjórar), Music makes the difference. Music, brain development and learning (bls. 241-250). Virginia: The National Association for Music Education.

Sigurður Kristinsson. (2013. Siðfræði rannsókna og siðanefndir. Í Sigríður Halldórsdóttir (ritstjóri), Handbók i aðferðafreði rannsókna (bls. 71-88). Akureyri: Háskólinn á Akureyri.

Sigurlína Davíðsdóttir. (2003). Eigindlegar eða megindlegar rannsóknaraðferðir? Í Sigriłur Halldórsdóttir og Kristján Kristjánsson (ritstjórar), Handbók i aðferðafraði og rannsóknum í heilbrigdisvísindum (bls. 219-235). Akureyri: Háskólinn á Akureyri.

Skóla- og frístundasvið Reykjavíkurborgar. (2014). Skrekkur. Hæfileikakeppni skóla- og frístundasviðs. Sótt af https://reykjavik.is/sites/default/files/ymis_skjol/skjol_utgefid_efni/skyrsla_rynihops_skrekks-020914_loka_2. pdf 
Sóley S. Bender. (2013. Samræður í rýnihópum. Í Sigríður Halldórsdóttir (ritstjóri), Handbók i aðferðafraði rannsókna (bls. 299-312). Akureyri: Háskólinn á Akureyri.

Tochon, F. V. (2010). Deep education. Journal for Educators, Teachers and Trainers 1, 1-12. Sótt af https://www. researchgate.net/publication/235902039_Deep_Education

Vísindasiðareglur Háskóla Íslands. (2014). Sótt af https://www.hi.is/sites/default/files/atli/pdf/log_og_reglur/ vshi_sidareglur_16_1_2014.pdf

Wilcox, E. (2000). Straight talk about music and brain research. Í A. Shafer og M. Blakeslee (ritstjórar), Music makes the difference. Music, brain development and learning (bls. 10-15). Virginia: The National Association for Music Education.

Østern, T. P. (2015). To body. Í S. Schonmann (ritstjóri), International yearbook for research in arts education (bls. 152-155). New York: Waxmann.

Østern, T. P. og Channells, P. (2016). Deep learning and teaching as affordances of inclusive dance and arts education. İ A. B. Sæbø (ritstjóri), International yearbook for research in arts education (bls. 123-131). New York: Waxmann.

Jóna Guðrún Jónsdóttir og Rannveig Björk Porkelsdóttir. (2020).

Tíminn sem ég man eftir: Ávinningur nemenda af pátttöku í Skrekk, hæfileikakeppni grunnskóla Reykjavíkurborgar

Netla - Veftímarit um uppeldi og menntun. Menntavísindasvið Háskóla Íslands.

Sótt af http://netla.hi.is/greinar/2020/ryn/11

DOI: https://doi.org/10.24270/netla.2020.11 